\title{
Hypertension and other morbidities with Cushing's syndrome associated with corticosteroids: a review
}

This article was published in the following Dove Press journal:

Integrated Blood Pressure Control

3 February 20II

Number of times this article has been viewed

\author{
Melpomeni Peppa' \\ Maria Krania' \\ Sotirios A Raptis 2,3 \\ 'Endocrine Unit, ${ }^{2}$ Second Department \\ of Internal Medicine-Propaedeutic, \\ Research Institute and Diabetes \\ Center, Athens University Medical \\ School, Attikon University Hospital, \\ Athens, Greece; ${ }^{3}$ Hellenic National \\ Diabetes Center for the Prevention, \\ Research, Treatment of Diabetes and \\ its Complications (HNDC), Athens, \\ Greece
}

\begin{abstract}
Corticosteroids constitute an ideal treatment for various inflammatory and autoimmune disorders due to their anti-inflammatory and immunomodulatory actions. However, corticosteroids have a considerable number of side effects, including hypertension, diabetes, lipid disorders, sleep apnea, osteoporosis, myopathy, and disorders of coagulation and fibrinolysis, which are components of Cushing's syndrome (CS). Corticosteroid-induced side effects are dependent on the formulation, route, dose, and time of exposure. However, the underlying pathogenetic mechanisms have not been clearly defined. A large body of evidence supports the role of an imbalance between vasoconstriction and vasodilation with possible links to nitric oxide, prostanoids, angiotensin II, arginine vasopressin, endothelins, catecholamines, neuropeptide Y, and atrial natriuretic peptide. Increased oxidative stress, renin-angiotensin system activation, increased pressor response, metabolic syndrome, and sleep apnea appear to be pathogenetically involved as well. The ideal treatment is the withdrawal of corticosteroids, which is most often impossible due to the exacerbation of the underlying disease. Alternatively, a careful plan, including the proper selection of the formulation, time, and route, should be made, and each side effect should be treated properly. The focus of the research should be to develop synthetic corticosteroids with anti-inflammatory effects but fewer metabolic effects, which so far has been unsuccessful.
\end{abstract}

Keywords: corticosteroids, hypertension, iatrogenic Cushing's syndrome

\section{Introduction}

It is estimated that up to $0.5 \%$ of the US population are on chronic corticosteroid therapy for various inflammatory and autoimmune disorders. ${ }^{1,2}$ Annually, $\sim 10$ million new prescriptions for oral corticosteroids are issued in the US. A minority of patients use corticosteroids without being aware of this, due to their use in the black market. Corticosteroids have been used, along with hydroquinone and mercury, as ingredients in a variety of skin lightening (bleaching) cosmetics and toiletries that are widely used in African countries. ${ }^{3}$ Over-the-counter combination preparations of steroids with other drugs such as antifungals may lead to unsupervised and inappropriate use of topical corticosteroids. ${ }^{2,4,5}$ Cases of factitious Cushing's syndrome (CS) from surreptitious use of corticosteroids have been described. ${ }^{6}$ Corticosteroids as an ingredient of a black market drug used by addicts to help them through the narcotic withdrawal stage were responsible for an outbreak of CS in Tehran in $2008 .^{7}$

Corticosteroids have been the medication of choice in various disorders, based on their undoubted benefits from their anti-inflammatory and immunomodulatory actions. However, they are also complicated by a considerable number of side
Correspondence: Melpomeni Peppa Endocrine Unit, Second Department of Internal Medicine-Propaedeutic, Research Institute and Diabetes Center, Athens University Medical School, Attikon University Hospital, Athens, Greece

Tel +302105831255

Fax +302105326454

Email molypepa@otenet.gr
(C) 20I I Peppa et al, publisher and licensee Dove Medical Press Ltd. This is an Open Access article which permits unrestricted noncommercial use, provided the original work is properly cited. 
effects, including CS. The clinical presentation of CS often strikes with the use of high doses of corticosteroids. ${ }^{1,2}$ Symptoms include central obesity, plethora, easy bruising, thin skin, striae, myopathy, depression or psychosis, poor wound healing, increased incidence of infection, glaucoma and other ocular disease, and hypertension (HT). Hirsutism and other virilizing features are uncommon clinical findings due to nonsignificant increases in androgens. Avascular necrosis and spinal epidural lipomatosis constitute a complication of corticosteroid-induced CS. ${ }^{1,2}$

All synthetic derivatives that are used clinically, including prednisone, prednisolone, methylprednisolone, dexamethasone (DX), betamethasone, and triamcinolone, have the potential for adverse effects and CS. ${ }^{2}$ Which of these agents is most likely to cause CS has not been fully clarified due to the complex interaction of many factors involved in this process. ${ }^{2}$ It appears that it is dependent on the formulation used, pharmacokinetics, affinity for the glucocorticoid receptor, biologic potency, duration of action, and different levels of sensitivity in individual patients. ${ }^{2}$ Oral corticosteroid therapy has been well correlated with CS, and most physicians are aware of the dangers, having always to balance the cost-effect ratio. ${ }^{2}$ According to accumulated data, topical, aerosol, inhaled, and injectable corticosteroid therapy may also have adverse effects, including CS.,8-12 There have been several cases of children who received intralesional injections into keloid scars or other wounds (such as burns) and developed CS that persisted for a long time (up to 9 months). ${ }^{13}$ Cases of CS have also been reported in patients under treatment with paraspinal depot injections. ${ }^{14}$ Additional unusual cases include CS induced by serial occipital nerve blocks containing triamcinolone. ${ }^{15}$ Corticosteroid-related side effects including CS are common in patients with cystic fibrosis or HIV infection, which need combined treatments including budesonide and itraconazole or fluticasone propionate and ritonavir. ${ }^{11,12,16,17}$

Another critical determinant of the corticosteroid-induced side effects including CS is the dosage needed to control the disease. High doses of corticosteroids even for a short time or long-term use of agents with lower potency and short half-lives (hydrocortisone and cortisone) have been associated with CS. However, the prediction of dosages at which CS will develop is a complicated phenomenon that depends on a variety of factors. ${ }^{1,2}$ Thus, the cost-effect ratio has to be estimated in each case, and a careful plan should be made before starting treatment with corticosteroids. This review will discuss the critical determinants and underlying pathogenetic mechanisms of CS associated with corticosteroids.

\section{Morbidities associated with corticosteroid-related CS Corticosteroid-induced CS and HT}

HT is a prominent feature in patients with corticosteroidinduced CS, occurring in up to $20 \%$ of cases, and is dose dependent. ${ }^{1,2,18,19} \mathrm{~A}$ variety of mechanisms has been proposed to explain its pathogenesis. ${ }^{18,19}$

A large body of evidence supports the theory that corticosteroids induce an imbalance between vasoconstriction and vasodilation, favoring vasoconstriction, resulting in HT. ${ }^{18,19}$ According to in vitro, in vivo, and also human data, increased vasoconstriction is in large part mediated by increased endothelin-1 synthesis and secretion. ${ }^{20-22}$ Increased cytosolic calcium levels downregulate the expression of the $\mathrm{Na}-\mathrm{Ca}$ exchanger and increased erythropoeitin levels have also been pathogenetically involved in corticosteroidinduced vasoconstriction and HT. ${ }^{23,24}$ Accumulating data suggest that increased sympathetic activity, reflected in the increased synthesis of catecholamines and a1 $\beta$-adrenergic receptor expression, is an important underlying pathogenetic mechanism as well. ${ }^{18,19}$ The increased synthesis of catecholamines is due to increased expression and activity of various enzymes involved in the catecholamine biosynthesis, including tyrosine hydroxylase and phenylethanolamine $\mathrm{N}$-methyltransferase. Elevated epinephrine and norepinephrine levels in plasma and adrenal medulla and increased expression and activity of tyrosine hydroxylase have been found in hypertensive rats treated with subcutaneous injections of dexamethasone (DX; $1 \mathrm{mg} / \mathrm{kg} /$ day for 2 days). ${ }^{25}$ Elevated levels of plasma dopamine and epinephrine have been found in humans treated with a single dose of $2 \mathrm{mg}$ DX. ${ }^{26}$ In both studies, the observed effects were blocked by the administration of alpha-methyl-p-tyrosine, an inhibitor of tyrosine hydroxylase. ${ }^{25,26}$ Increased activity of phenylethanolamine $N$-methyltransferase has been found in both intact and adrenalectomized rats treated with subcutaneous injections of DX (1 mg/kg/day for $12-14$ days). ${ }^{27,28} \mathrm{In}$ addition, in vitro, in vivo, and human studies suggest that corticosteroids alter the availability of $\alpha 1$-adrenergic receptors in vascular smooth muscles, leading to increased vascular reactivity, pressor responsiveness, and HT. ${ }^{29-31}$

Increased corticosteroid-induced vasoconstriction and thus HT are also mediated through enhanced synthesis and action of vasoactive substances and their receptors, including 
neuropeptide Y (NPY), arginine vasopressin (AVP), and atrial natriuretic peptide (ANP). ${ }^{19,20}$ Increased corticosteroidinduced NPY gene expression and tissue content in neuroendocrine tissue and cell lines have been associated with vasoconstriction. ${ }^{32}$ Coadministration of AVP and DX ( $1.8 \mathrm{mg} / \mathrm{kg} /$ week for 2 weeks) to normotensive rats resulted in dose-dependent increases in mean arterial pressure, which can be reversed by the administration of d(CH2)5Tyr(Me) AVP, an AVP-V1 receptor antagonist, suggesting the role of the V1aAVP receptor in DX-induced HT. ${ }^{31,33,34}$ Increased expression of atrial, ventricular, pulmonary ANP genes and plasma ANP levels have been found in both intact and adrenalectomized rats treated with DX (1 and $4 \mathrm{mg} / \mathrm{kg} /$ day for 2 days). ${ }^{31,35}$ Higher ANP levels have been observed in atrial slices and extracts obtained from rats treated with DX (intraperitoneally, $0.1 \mathrm{mg} / \mathrm{kg} /$ day for 4 days). ${ }^{36,37}$

Another interesting issue is the role of renin-angiotensin system activation in the development of corticosteroidinduced HT. ${ }^{18,19}$ Corticosteroids act directly at the liver site, enhancing the synthesis of the plasma renin substrate (angiotensinogen). ${ }^{31,38}$ Experimental studies using saralasin, an angiotensin antagonist, and SQ14225, an angiotensin-converting enzyme, partly prevented HT in rats treated with DX $(0.17-0.27 \mathrm{mg} / \mathrm{kg} /$ day $)$, suggesting the partial contribution of angiotensin II in terms of increased synthesis or sensitivity in the development of DX-induced HT. ${ }^{38}$

A large body of evidence supports the theory that apart from the increased corticosteroid-induced synthesis and secretion of vasoactive substances, an increased sensitivity and reactivity of various tissues to their action, reflected in increased vascular pressor responsiveness, has also been observed. ${ }^{31,39-41}$ A reduced threshold and increased maximal response to norepinephrine has been observed in rat mesenteric vasculatures isolated from hypertensive rats treated with DX orally (7-9.5 mg/kg/day for 28 days). ${ }^{42,43}$

AVP, but not norepinephrine or angiotensin II infusion, elicited increased pressor response in DX-induced hypertensive rats $\left(257 \mathrm{mg} / \mathrm{kg} /\right.$ day for 2 weeks). ${ }^{33}$ Infusion of angiotensin II in humans treated with DX (orally, $3 \mathrm{mg} /$ day) resulted in increased forearm vascular resistance. ${ }^{39,44}$ These effects seem to be mediated through changes in the activity of sodium/potassium pump ${ }^{45}$ and function of glucocorticoid ${ }^{46}$ and mineralocorticoid ${ }^{47}$ receptors as well. Administration of angiotensin II and AVP in DX-treated experimental animals was accompanied by a reduction in the threshold of the inositol triphosphate production and HT, an effect that was blocked by the administration of a specific glucocorticoid receptor antagonist RU38486 but not spironolactone or RU28318, type I mineralocorticoid receptor antagonists. ${ }^{46,48} \mathrm{DX}$-induced stimulation of vascular angiotensin II type 1 receptor has also been observed and linked to HT. ${ }^{47}$ Furthermore, corticosteroids seem to induce HT by binding to mineralocorticoid receptors. ${ }^{49}$ It has been supported that although corticosteroids activate both mineralocorticoid and glucocorticoid receptors, they exhibit a higher affinity for glucocorticoid receptors than with mineralocorticoid receptors. ${ }^{50}$

On the other hand, corticosteroids negatively affect various vasodilatory systems. ${ }^{18,19}$ Corticosteroid-induced HT has been associated with nitric oxide (NO) deficiency through a range of negative influences on the NO biosynthetic pathways, involving i) alteration in the activity and expression of $\mathrm{NO}$ synthase, ii) decreased availability of tetrahydrobiopterin (BH4), and iii) decreased NO precursor L-arginine. ${ }^{51-53} \mathrm{NO}$ deficiency might also be the result of NO interaction with excess superoxide to form a powerful oxidant, peroxynitrite, which leads to NO inactivation and deficit. ${ }^{54,55}$

According to experimental data, corticosteroids seem to negatively affect the production of other vasodilatory substances as well, such as prostacyclin, prostaglandin E2 (PGE2), and kallikrein. ${ }^{56-58}$

The end result of the afore mentioned alterations is hemodynamic changes in various vascular beds. A large dose of oral DX $(0.5 \mathrm{mg} / \mathrm{kg} /$ day $)$ in dogs was accompanied by a reduction in cardiac output and an increase in calculated total peripheral resistance. ${ }^{31}$ In humans, oral DX (1 mg three times daily for 7 days) increased mean and total peripheral vascular resistance without affecting the cardiac output. ${ }^{39}$ Limited studies support an effect of DX on the regional hemodynamics as well. Intravenous $24 \mathrm{~h}$ infusion of DX $(125 \mathrm{mg} / \mathrm{kg} / \mathrm{h})$ increased the mean arterial pressure, and decreased renal and mesenteric blood flow and conductance. ${ }^{59}$ However, it remains unclear whether this is a coexisting feature or a pathogenic mechanism of corticosteroid-induced HT.

Coexisting metabolic abnormalities appear to mediate and accentuate the corticosteroid-induced HT. Obesity is associated with a reduction in urine sodium excretion, increased plasma and extracellular fluid volume, and HT. ${ }^{18,19}$ Insulin resistance leads to sodium and water retention, increased sympathoadrenal system activity, local reninangiotensin system activation, vascular hypertrophy, increased vascular resistance, and HT. ${ }^{18,19}$ Sleep apnea has also been associated with HT through increased sympathetic tone during hypoxemic episodes, insulin resistance, and diabetic autonomic neuropathy. ${ }^{18,19}$ 
It seems that corticosteroids regulate blood pressure by exerting their effects at the central nervous system as well. Subcutaneous tritium-labeled DX administration in rats resulted in localization of radioisotope in the thalamus (lateral nucleus), hypothalamus (arcuate, ventromedial, periventricular, and paraventricular nuclei), and cell bodies of locus ceruleus, area postrema, and nucleus tractus solitarii, indicating that systemically administered DX passes to the brain and cerebrospinal fluid. ${ }^{60-62}$ An interesting theory has been developed suggesting that corticosteroids induce central nervous system activation and HT, but this has to be further evaluated. ${ }^{62}$ This effect might be mediated through direct interaction of corticosteroids with $\gamma$-aminobutyric acid type A and B receptors and nontranscriptional activation of phosphatidylinositol 3-kinase/protein kinase Akt pathway, possibly mediated by the glucocorticoid receptor.

\section{Corticosteroid-induced CS} and osteoporosis

Osteoporosis constitutes an important component of corticosteroid-induced CS in children and adults. ${ }^{1,2}$ Bone loss appears to be fastest in the first 6 months of therapy and persists at a slower rate thereafter, resulting in osteopenia and osteoporosis. Trabecular bone and the cortical rim of vertebral bodies appear to be more susceptible to the effects of corticosteroids, improving rapidly after their withdrawal. In addition, fractures may occur in $30 \%-50 \%$ of corticosteroid-treated patients independently of bone mineral density differences. ${ }^{63,64}$ Long-term use of corticosteroids in asthmatic patients has been associated with increased rib and vertebral fractures. ${ }^{65} \mathrm{~A}$ retrospective cohort study of 244,235 adults on oral corticosteroids documented a dose-dependent increase in nonvertebral, hip, forearm, and vertebral fractures, occurring even with low doses of corticosteroids (2.5 mg/day) ${ }^{66} \mathrm{~A}$ meta-analysis of 42,500 men and women from seven prospective cohorts showed that current or prior corticosteroid use has been associated with increased fracture risk. ${ }^{67}$ There is a large body of evidence indicating that inhaled corticosteroids negatively affect bone metabolism, as well as when they are taken orally. ${ }^{68,69}$ However, the percentage of bone loss and the real fracture risk attributed to corticosteroids is difficult to be estimated in those patients, due to the multifactorial origin of altered bone metabolism.

Corticosteroids negatively affect calcium metabolism and bone remodeling, leading to decreased bone formation and increased bone resorption. Corticosteroids decrease intestinal calcium absorption and renal tubular reabsorption of calcium, resulting in hypercalciuria, secondary hyperparathyroidism, and increased bone resorption. ${ }^{63,64}$ Corticosteroids have a negative impact on osteoblastogenesis as well by reducing synthesis of type 1 collagen and insulin-like growth factor, altering the binding and thus the anabolic effects of transforming growth factor- $\beta$, inhibiting Wnt signaling, and inducing apoptosis of osteoblasts and osteocytes. ${ }^{63,64}$ Decreased activity of type 1-11ß-hydroxysteroid dehydrogenase and increased activity of type 2-11 $\beta$-hydroxysteroid dehydrogenase by circulating inflammatory cytokines, the antagonistic effect of corticosteroids on parathormone and testosterone, seem to represent underlying pathogenetic mechanisms. On the other hand, corticosteroids stimulate osteoclast proliferation by suppressing synthesis of osteoprotegerin, stimulating production of the receptor activator of nuclear factor $\mathrm{KB}$ and decreasing estrogen and androgen production, leading to increased osteoclastic bone resorption. ${ }^{63,64,70-72}$

\section{Corticosteroid-induced CS and disorders of the coagulation/fibrinolysis system}

Thromboembolic disease is an important and serious complication in patients with CS, as it is associated with increased morbidity and mortality. ${ }^{1,2,73}$ Small clinical studies in patients with CS have shown an activation of the coagulation system reflected in higher levels of plasma von Willebrand factor VIII, factor IX, and factor XII; decreased fibrinolytic activity reflected in lower levels of PAI-1, tPA, or euglobulin clot lysis time; and increased levels of factors XII, XI, IX, and VIII plasminogen and a 2-antiplasmin..$^{74,75}$ These effects have been closely related to corticosteroids, as they were fully reversed after surgical treatment. In a similar way, exogenous corticosteroids cause disorders in the coagulation and fibrinolytic systems, reflected in increased synthesis/secretion of PAI-1, and increased levels of thrombin-antithrombin complex increased plasma factor VII, factor VIII, factor XI, and fibrinogen levels. ${ }^{76-78}$

\section{Corticosteroid-induced CS and muscloskeletal disorders}

Myopathy seems to be a common feature in CS, clinically expressed as the inability to rise from a crouching position, due to the adverse effects of corticosteroids on the proximal muscles of the lower limb and the shoulder girdle..$^{1,2,79}$ Corticosteroids affect type 2B or 'phasic' muscle fibers (fast twitch) causing atrophy (but not necrosis), resulting in reduced muscle protein synthesis. This effect is mediated through increased oxidative phosphorylation, inhibition 
of protein synthesis, and impairment of muscle membrane excitability. ${ }^{79}$

The acute form of myopathy involves proximal and distal muscle weakness, is positively correlated with elevated serum creatinine phosphokinase levels, is an indicator of focal and diffuse muscle necrosis, is mediated by hypokalemia, or constitutes the end result of a direct effect of corticosteroids on skeletal muscle. This type of myopathy may take between 6 weeks and several months to resolve, even after the discontinuation of corticosteroids. The chronic form is more insidious in onset, primarily involves proximal muscle groups, and is characterized by typically normal or only slightly elevated creatinine phosphokinase levels with no evidence of focal or diffuse muscle necrosis. Although there is no direct correlation with dosage, patients who receive even small amounts of prednisone (ie, $10 \mathrm{mg} /$ day) can develop myopathy. ${ }^{80,81}$

\section{Corticosteroid-induced CS and metabolic syndrome}

Impaired glucose tolerance, diabetes, dyslipidemia, and fatty liver disease are common findings in patients treated with corticosteroids. ${ }^{82-84}$ Not only experimental but also human data support the theory of corticosteroids having an effect on various sites involved in protein, lipid, and glucose metabolism, including skeletal muscle, liver, and adipose tissue. Corticosteroids induce insulin resistance in skeletal muscle by directly interfering with the insulin signaling cascade. Decreased glucogen synthesis rates and glycogen synthase concentration and activity have been found in skeletal muscle biopsies of healthy subjects on $4 \mathrm{mg}$ DX for 4 days $^{85}$ and patients on long-term treatment with high doses of corticosteroids following renal transplantation. ${ }^{86}$ Skeletal muscle insulin resistance is further aggravated by corticosteroid-induced protein catabolism with concomitant atrophy-related decrease in total muscle area and elevated circulating aminoacids, ${ }^{87}$ which negatively affect insulin signaling ${ }^{88}$ glucose uptake, and glycogen synthesis in muscle. ${ }^{89}$ In addition, corticosteroids induce whole body lipolysis, ${ }^{89}$ resulting in increased plasma levels of free fatty acids and triglycerides ${ }^{90,91}$ with deleterious effects in skeletal muscle insulin sensitivity and glucose uptake. Corticosteroids induce hepatic insulin resistance as well, directly by interference with insulin signaling and indirectly by elevating free fatty acid and triglyceride supply to the liver. ${ }^{92}$ Thus, increased endogenous glucose production has been observed, especially in the postprandial state, as was demonstrated in healthy subjects following short-term exposure to corticosteroids. ${ }^{84,93,94}$ Corticosteroids increase body fat content and alter body fat distribution by regulating hormone sensitive lipase and lipoprotein lipase activity. ${ }^{95}$ In addition, corticosteroids modulate adipose tissue biology by altering the secretion of adipokines either directly or through insulin resistance. ${ }^{96}$ In addition to inducing insulin resistance, corticosteroids might exert an inhibitory effect on $\beta$ cells, which is dependent on duration of exposure, dosage, and susceptibility of the population exposed. A prolonged exposure (2-5 days) of healthy subjects to high doses of corticosteroids resulted in fasting hyperinsulinemia and increased insulin secretion, possibly to compensate for the corticosteroid-induced insulin resistance. ${ }^{97-99}$ However, in a susceptible population, such as people with a reduced insulin sensitivity before treatment, people who are healthy first-degree relatives of patients with diabetes, and obese women, this compensation failed, resulting in $\beta$ cell failure and diabetes. ${ }^{88,98-100}$ Thus, corticosteroids induce insulin resistance, impaired glucose metabolism, obesity, and central obesity, all of which are components of metabolic syndrome, which has been associated with increased morbidity and mortality from cardiovascular disease.

\section{Corticosteroid-induced CS and cardiovascular disease}

Patients with corticosteroid-induced CS exhibit increased cardiovascular morbidity and mortality. ${ }^{1,2,101-103}$ Increased mortality from cardiovascular disease has been reported in patients with asthma, chronic obstructive pulmonary disease, inflammatory arthritis, and giant cell arteritis. ${ }^{104-106}$ A population-based study showed that patients who were exposed to systematic corticosteroids in a dose greater than the equivalent of $7.5 \mathrm{mg}$ of prednisolone daily had substantially higher rates of cardiovascular disease during 1-5 years of follow-up, namely myocardial infarction, heart failure, and cerebrovascular disease. ${ }^{102,103}$ It has to be mentioned that this association was not evident in patients treated with low doses or 'nonsystemic' (eg, topical and rectal) corticosteroids.

Corticosteroids appear to have a direct causal effect relationship with cardiovascular disease, which is dependent on the dose, duration, cumulative dose of exposure, and route of administration. Whether, and to what extent, the increased risk is mediated through the disease background for cardiovascular disease and the induction of several risk factors for cardiovascular disease and represents a direct corticosteroid effect that is much higher than their anti-inflammatory and antiproliferative actions cannot be answered by the existing data. ${ }^{107,108}$ 


\section{Corticosteroid-induced CS and fetal programming}

Much interest has been focused over the last 5 years on the role of corticosteroids in fetal programming. ${ }^{1,2,109}$ The key mediators appear to be the hypothalamic-pituitaryadrenal axis, the glucocorticoid receptor, and the expression of type $2-11 \beta$-hydroxysteroid dehydrogenase genes in a range of tissues. The administration of corticosteroids to mothers to promote maturation of organs in fetuses, to prevent a number of life-threatening complications of preterm birth, and to reduce the effects of congenital adrenal hyperplasia has undoubted short-term benefits and also potential long-term adverse effects. ${ }^{109,110}$ A large body of experimental and human evidence supports the theory that corticosteroids appear to be involved in a dose-dependent manner in the fetal programming of adult diseases. ${ }^{11}$ Corticosteroid-related fetal programming of adult HT is exerted through the effects on maturation of tissues involved in the control of blood pressure, such as glomerular number and kidney size, in the expression of catecholamine receptors and second messenger systems in renal and vascular tissue, and by affecting growth factors and carbohydrate and fat homeostasis. In addition, corticosteroids potentiate vasoconstrictor effects on the vasculature and regulate the synthesis of catecholamines, NO, and angiotensinogen. ${ }^{12,113}$ HT is coupled to tissue-specific increases in glucocorticoid receptor expression and downregulation of type 2-11ßhydroxysteroid dehydrogenase activity in the placenta, kidney, and adrenal, increasing sensitivity and overexposing organs to corticosteroids. Apart from inducing HT, corticosteroids are involved in the fetal programming of type 2 diabetes, cardiovascular disease, other manifestations of the metabolic syndrome, several central nervous system functions, and psychiatric syndromes. However, the exact underlying pathogenetic mechanisms are still unclear and need to be further elucidated.

\section{Exogenous vs endogenous corticosteroid-induced CS and HT}

Although the clinical presentation of CS is quite similar from endogenous cortisol overproduction and exogenous corticosteroids, it also has some differences, mainly in the more striking clinical manifestations, due to the use of high doses of corticosteroids. ${ }^{1,2} \mathrm{CS}$ as a result of the long-term usage of corticosteroids has less hirsutism and other virilizing features due to nonsignificant increases in androgens. In addition, HT is less profound in exogenous corticosteroid-induced CS compared with endogenous CS, depending on the form used. In contrast, avascular necrosis and spinal epidural lipomatosis occur primarily in the setting of corticosteroid-induced CS. ${ }^{1,2}$ In addition, a kinetic difference has to be mentioned. In contrast to cortisol, most synthetic corticosteroids bind to albumin and not to cortisol-binding globulin or circulate as free steroids with a much higher affinity for the glucocorticoid receptor. With HT, both forms of CS exhibit some similarities and some differences.

In both forms of CS, the development of HT is rapid. Supraphysiological oral cortisol doses ( 80 and $200 \mathrm{mg}$ /day) in humans can cause HT within $24 \mathrm{~h}$, with peak blood pressure occurring at day 4 or 5 of treatment. ${ }^{114,115}$ In addition, subcutaneous DX (10 mg/day) in rats and oral DX $(0.5 \mathrm{mg} / \mathrm{kg} / \mathrm{day})$ in dogs and humans ( $3 \mathrm{mg} /$ day) increases blood pressure within $1-2$ days. ${ }^{31}$ According to in vitro and in vivo studies, the same pattern is observed in endogenous CS as well. ${ }^{116,117}$ HT, in both clinical entities, is independent of mineralocorticoid activity and sodium loading or retention. ${ }^{49,118}$ However, in endogenous CS, sodium excess can magnify the hypertensive response. ${ }^{119,120}$ Increased oxidative stress, reflected in increased superoxide production and elevated levels of plasma F2-isoprostanes, constitutes a common underlying disorder in both forms of CS and is prevented and reversed by antioxidants (folic acid, $\mathrm{N}$-acetylcysteine, tempol, and apocynin) but not with BH4 or allopurinol. ${ }^{121-123}$ In both conditions, HT has been associated with decreased NO bioavailability, reflected in decreased plasma reactive nitrogen intermediates (nitrate/nitrite). ${ }^{122,123}$

Although HT, in both forms of CS, is associated with increased oxidative stress and NO deficiency and inactivation, blood pressure response to treatments known to modify the synthesis of $\mathrm{NO}$ and superoxide seems to be variable. L-Arginine treatment $(500 \mathrm{mg} / \mathrm{kg} /$ day $)$ increased plasma nitrate/nitrite concentrations but failed to prevent HT in corticosteroid-treated rats. ${ }^{53,121}$ In contrast, in endogenous CS, HT was prevented and partly reversed by L-arginine treatment. ${ }^{124}$ Aspirin, an antioxidant and nonselective cyclooxygenase inhibitor, prevented and partly reversed HT related to endogenous but not exogenous CS. ${ }^{125}$ Vasopressin antagonism with an AVP-V1 receptor antagonist significantly decreased mean arterial pressure in exogenous but not endogenous CS-related hypertensive rats. ${ }^{33}$ Both forms of HT exhibit a different response to glucocorticoid receptor antagonism, suggesting a different degree of receptor activation in both situations. Thus, dehydroepiandrosterone, an endogenous steroid with antiglucocorticoid activity, prevented corticosteroid-induced but not endogenous 
cortisol-induced HT. ${ }^{31,126}$ In summary, it appears that HT due to endogenous or exogenous CS involves either different pathophysiological mechanisms or different degree of perturbations of the same mechanisms.

\section{Treatment}

Patients with autoimmune or inflammatory disorders should be on long-term use of corticosteroids and may develop HT and other morbidities associated with corticosteroid-induced CS. The ideal treatment is the withdrawal of corticosteroids before the onset of comorbidities. However, this is practically impossible, as it is associated with exacerbation of the underlying disease. When possible, corticosteroids should be gradually withdrawn. The use of corticosteroids in low dosages or on alternative days results in fewer metabolic effects and also helps in the prevention of corticosteroid-related pathology. Thus, each patient should be treated individually, following a careful, properly designed plan. In most cases, patients should be treated for corticosteroid-related morbidities. For HT, eplerenone, angiotensin receptor antagonists, and angiotensin-converting enzyme inhibitors are indicated. Weight loss is encouraged through changes in the lifestyle. Medications that improve insulin resistance, such as biguanides and peroxisome proliferator-activated receptor agonists, should be added. Treatment of sleep apnea with a continuous positive airway pressure device appears to be generally effective in controlling not only apnea but also HT, insulin resistance, and increased risk for cardiovascular disease. Bisphosphonates are the first-line choice for prevention or treatment of osteoporosis, with teriparatide as the secondline option; calcium and vitamin D supplements should be coprescribed in the majority of individuals. Muscle biopsy is recommended in patients who require long-term corticosteroid treatment and develop weakness during therapy. Phenytoin has been suggested for treatment of corticosteroid myopathy, but this still needs further research. In the absence of prospective randomized clinical trials, there is currently general agreement that patients with CS should be treated as having a prothrombotic disorder. However, future large prospective trials are needed to evaluate the type, intensity, and duration of thromboprophylaxis in patients with either endogenous CS or iatrogenic CS.

\section{Conclusion}

Corticosteroid-induced CS constitutes a major health problem with difficult handling. A careful plan for treatment, namely formulation, route, dose, and time of exposure, should be properly evaluated individually before patients start corticosteroids use. Corticosteroid-related complications should be treated properly, if evident, and prevention strategy involves changes in lifestyle and treatment with appropriate agents. The focus of the research should be on developing synthetic steroids with anti-inflammatory but fewer metabolic effects, which so far has been unsuccessful.

\section{Disclosure}

The authors report no conflicts of interest in this work.

\section{References}

1. Pivonello R, de Martino MC, de Leo M, Lombardi G, Colao A. Cushing's syndrome. Endocrinol Metab Clin North Am. 2008; 37(1):135-149, ix.

2. Chrousos GP. Glucocorticoid therapy. In: Felig P, Frohman L, editors. Endocrinology and Metabolism. 4th ed. New York: McGraw-Hill, Incorporated; 2001:609-632.

3. Olumide YM, Akinkugbe AO, Altraide D, et al. Complications of chronic use of skin lightening cosmetics. Int J Dermatol. 2008; 47(4):344-353.

4. Castanedo-Cazares JP, Lopez-Lucio RH, Moncada B. Cushing syndrome following the prescription of antifungal, antibiotic, corticosteroid cream. Int J Dermatol. 2003;42(4):318.

5. Weber SL. Cushing's syndrome attributable to topical use of lotrisone. Endocr Pract. 1997;3(3):140-144.

6. Villanueva RB, Brett E, Gabrilove JL. A cluster of cases of factitious Cushing's syndrome. Endocr Pract. 2000;6(2):143-147.

7. Azizi F, Jahed A, Hedayati M, et al. Outbreak of exogenous Cushing's syndrome due to unlicensed medications. Clin Endocrinol (Oxf). 2008;69(6):921-925.

8. Ermis B, Ors R, Tastekin A, Ozkan B. Cushing's syndrome secondary to topical corticosteroids abuse. Clin Endocrinol (Oxf). 2003; 58(6):795-796.

9. Lipworth BJ. Systemic adverse effects of inhaled corticosteroid therapy: a systematic review and meta-analysis. Arch Intern Med. 1999;159(9):941-955.

10. Perry RJ, Findlay CA, Donaldson MD. Cushing's syndrome, growth impairment, and occult adrenal suppression associated with intranasal steroids. Arch Dis Child. 2002;87(1):45-48.

11. Kumar S, Singh RJ, Reed AM, Lteif AN. Cushing's syndrome after intra-articular and intradermal administration of triamcinolone acetonide in three pediatric patients. Pediatrics. 2004;113(6):1820-1824.

12. Lansang MC, Farmer T, Kennedy L. Diagnosing the unrecognized systemic absorption of intra-articular and epidural steroid injections. Endocr Pract. 2009;15(3):225-228.

13. Teelucksingh S, Balkaran B, Ganeshmoorthi A, Arthur P. Prolonged childhood Cushing's syndrome secondary to intralesional triamcinolone acetonide. Ann Trop Paediatr. 2002;22(1):89-91.

14. Edmonds LC, Vance ML, Hughes JM. Morbidity from paraspinal depo corticosteroid injections for analgesia: Cushing's syndrome and adrenal suppression. Anesth Analg. 1991;72(6):820-822.

15. Lavin PJ, Workman R. Cushing syndrome induced by serial occipital nerve blocks containing corticosteroids. Headache. 2001;41(9): 902-904.

16. Bolland MJ, Bagg W, Thomas MG, Lucas JA, Ticehurst R, Black PN. Cushing's syndrome due to interaction between inhaled corticosteroids and itraconazole. Ann Pharmacother. 2004;38(1):46-49.

17. Gupta SK, Dube MP. Exogenous Cushing syndrome mimicking human immunodeficiency virus lipodystrophy. Clin Infect Dis. 2002; 35(6):E69-E71.

18. Saruta T, Suzuki H, Handa M, Igarashi Y, Kondo K, Senba S. Multiple factors contribute to the pathogenesis of hypertension in Cushing's syndrome. J Clin Endocrinol Metab. 1986;62(2):275-279. 
19. Magiakou MA, Smyrnaki P, Chrousos GP. Hypertension in Cushing's syndrome. Best Pract Res Clin Endocrinol Metab. 2006; 20(3):467-482.

20. Roubert P, Viossat I, Lonchampt MO, et al. Endothelin receptor regulation by endothelin synthesis in vascular smooth muscle cells: effects of dexamethasone and phosphoramidon. J Vasc Res. 1993; 30(3):139-144.

21. Kirilov G, Tomova A, Dakovska L, Kumanov P, Shinkov A, Alexandrov AS. Elevated plasma endothelin as an additional cardiovascular risk factor in patients with Cushing's syndrome. Eur $J$ Endocrinol. 2003;149(6):549-553.

22. Borcsok I, Schairer HU, Sommer U, et al. Glucocorticoids regulate the expression of the human osteoblastic endothelin A receptor gene. J Exp Med. 1998;188(9):1563-1573.

23. Smith L, Smith JB. Regulation of sodium-calcium exchanger by glucocorticoids and growth factors in vascular smooth muscle. J Biol Chem. 1994;269(44):27527-27531.

24. Macefield VG, Williamson PM, Wilson LR, Kelly JJ, Gandevia SC, Whitworth JA. Muscle sympathetic vasoconstrictor activity in hydrocortisone-induced hypertension in humans. Blood Press. 1998;7(4):215-222.

25. Kumai T, Asoh K, Tateishi T, et al. Involvement of tyrosine hydroxylase up regulation in dexamethasone-induced hypertension of rats. Life Sci. 2000;67(16):1993-1999.

26. Watanabe T, Noshiro T, Akama H, et al. Effect of dexamethasone on plasma free dopamine: dopaminergic modulation in hypertensive patients. Hypertens Res. 1995;18 Suppl 1:S197-S198.

27. Kennedy B, Elayan H, Ziegler MG. Glucocorticoid hypertension and nonadrenal phenylethanolamine N-methyltransferase. Hypertension. 1993;21(4):415-419.

28. Kennedy B, Ziegler MG. Cardiac epinephrine synthesis. Regulation by a glucocorticoid. Circulation. 1991;84(2):891-895.

29. Sakaue M, Hoffman BB. Glucocorticoids induce transcription and expression of the alpha $1 \mathrm{~B}$ adrenergic receptor gene in DTT1 MF-2 smooth muscle cells. J Clin Invest. 1991;88(2): 385-389.

30. Haigh RM, Jones CT. Effect of glucocorticoids on alpha 1-adrenergic receptor binding in rat vascular smooth muscle. $J$ Mol Endocrinol. 1990;5(1):41-48.

31. Nakamoto H, Suzuki H, Kageyama Y, et al. Characterization of alterations of hemodynamics and neuroendocrine hormones in dexamethasone induced hypertension in dogs. Clin Exp Hypertens $A$. 1991;13(4):587-606.

32. Edvinsson L, Ekblad E, Hakanson R, Wahlestedt C. Neuropeptide Y potentiates the effect of various vasoconstrictor agents on rabbit blood vessels. Br J Pharmacol. 1984;83(2):519-525.

33. Iijima F, Malik KU. Contribution of vasopressin in dexamethasoneinduced hypertension in rats. Hypertension. 1988;11(2 Pt 2): I42-I46.

34. Murasawa S, Matsubara H, Kizima K, Maruyama K, Mori Y, Inada M. Glucocorticoids regulate $\mathrm{V} 1 \mathrm{a}$ vasopressin receptor expression by increasing mRNA stability in vascular smooth muscle cells. Hypertension. 1995;26(4):665-669.

35. Gardner DG, Hane S, Trachewsky D, Schenk D, Baxter JD. Atrial natriuretic peptide mRNA is regulated by glucocorticoids in vivo. Biochem Biophys Res Commun. 1986;139(3):1047-1054.

36. Garcia R, Debinski W, Gutkowska J, et al. Gluco- and mineralocorticoids may regulate the natriuretic effect and the synthesis and release of atrial natriuretic factor by the rat atria in vivo. Biochem Biophys Res Commun. 1985;131(2):806-814.

37. Lachance D, Garcia R, Gutkowska J, Cantin M, Thibault G. Mechanisms of release of atrial natriuretic factor. I. Effect of several agonists and steroids on its release by atrial minces. Biochem Biophys Res Commun. 1986;135(3):1090-1098.

38. Klett C, Ganten D, Hellmann W, et al. Regulation of hepatic angiotensinogen synthesis and secretion by steroid hormones. Endocrinology. 1992;130(6):3660-3668.
39. Pirpiris M, Sudhir K, Yeung S, Jennings G, Whitworth JA. Pressor responsiveness in corticosteroid-induced hypertension in humans. Hypertension. 1992;19(6 Pt 1):567-574.

40. Sambhi MP, Weil MH, Udhoji VN. Pressor responses to norepinephrine in humans before and after corticosteroids. Am J Physiol. 1962;203: 961-963.

41. Lefer AM, Manwaring JL, Verrier RL. Effect of corticosteroids on the cardiovascular responses to angiotensin and norepinephrine. J Pharmacol Exp Ther. 1966;154(1):83-91.

42. Russo D, Fraser R, Kenyon CJ. Dexamethasone therapy selectively increases the sensitivity to noradrenaline of the rat mesenteric circulation. J Hypertens Suppl. 1989;7(6):S126-S127.

43. Russo D, Fraser R, Kenyon CJ. Increased sensitivity to noradrenaline in glucocorticoid-treated rats: the effects of indomethacin and desipramine. J Hypertens. 1990;8(9):827-833.

44. Griendling KK, Minieri CA, Ollerenshaw JD, Alexander RW. Angiotensin II stimulates NADH and NADPH oxidase activity in cultured vascular smooth muscle cells. Circ Res. 1994;74(6):1141-1148.

45. Stern N, Palant C, Ozaki L, Tuck ML. Dexamethasone enhances active cation transport in cultured aortic smooth muscle cells. Am J Hypertens. 1994;7(2):146-150.

46. Sato A, Suzuki H, Iwaita Y, Nakazato Y, Kato H, Saruta T. Potentiation of inositol trisphosphate production by dexamethasone. Hypertension. 1992;19(1):109-115.

47. Sato A, Suzuki H, Nakazato Y, Shibata H, Inagami T, Saruta T. Increased expression of vascular angiotensin II type 1A receptor gene in glucocorticoid-induced hypertension. J Hypertens. 1994;12(5): 511-516.

48. Grunfeld JP, Eloy L, Moura AM, Ganeval D, Ramos-Frendo B, Worcel M. Effects of antiglucocorticoids on glucocorticoid hypertension in the rat. Hypertension. 1985;7(2):292-299.

49. Williamson PM, Kelly JJ, Whitworth JA. Dose-response relationships and mineralocorticoid activity in cortisol-induced hypertension in humans. J Hypertens Suppl. 1996;14(5):S37-S41.

50. Rebuffat AG, Tam S, Nawrocki AR, et al. The 11-ketosteroid 11-ketodexamethasone is a glucocorticoid receptor agonist. Mol Cell Endocrinol. 2004;214(1-2):27-37.

51. Wallerath T, Witte K, Schafer SC, et al. Down-regulation of the expression of endothelial NO synthase is likely to contribute to glucocorticoid-mediated hypertension. Proc Natl Acad Sci U S A. 1999;96(23):13357-13362.

52. Simmons WW, Ungureanu-Longrois D, Smith GK, Smith TW, Kelly RA. Glucocorticoids regulate inducible nitric oxide synthase by inhibiting tetrahydrobiopterin synthesis and L-arginine transport. J Biol Chem. 1996;271(39):23928-23937.

53. Li M, Fraser T, Wang J, Whitworth JA. Dexamethasone-induced hypertension in the rat: effects of L-arginine. Clin Exp Pharmacol Physiol. 1997;24(9-10):730-732.

54. Pacher P, Beckman JS, Liaudet L. Nitric oxide and peroxynitrite in health and disease. Physiol Rev. 2007;87(1):315-424.

55. Iuchi T, Akaike M, Mitsui T, et al. Glucocorticoid excess induces superoxide production in vascular endothelial cells and elicits vascular endothelial dysfunction. Circ Res. 2003;92(1):81-87.

56. Zhang Y, Hu L, Mori TA, Barden A, Croft KD, Whitworth JA. Arachidonic acid metabolism in glucocorticoid-induced hypertension. Clin Exp Pharmacol Physiol. 2008;35(5-6):557-562.

57. Falardeau P, Martineau A. Prostaglandin I2 and glucocorticoid-induced rise in arterial pressure in the rat. $J$ Hypertens. 1989;7(8):625-632.

58. Nasjletti A, Erman A, Cagen LM, Baer PG. Plasma concentrations, renal excretion, and tissue release of prostaglandins in the rat with dexamethasone-induced hypertension. Endocrinology. 1984;114(3): 1033-1040.

59. Gardiner SM, Kemp PA, March JE, Bennett T. Effects of dexamethasone and SB 209670 on the regional haemodynamic responses to lipopolysaccharide in conscious rats. Br J Pharmacol. 1996;118(1): 141-149. 
60. Siegal T, Soti F, Biegon A, Pop E, Brewster ME. Effect of a chemical delivery system for dexamethasone (Dex-CDS) on peritumoral edema in an experimental brain tumor model. Pharm Res. 1997;14(5): 672-675.

61. Birmingham MK, Sar M, StumpfWE. Dexamethasone target sites in the central nervous system and their potential relevance to mental illness. Cell Mol Neurobiol. 1993;13(4):373-386.

62. Wang LL, Ou CC, Chan JY. Receptor-independent activation of GABAergic neurotransmission and receptor-dependent nontranscriptional activation of phosphatidylinositol 3-kinase/protein kinase Akt pathway in short-term cardiovascular actions of dexamethasone at the nucleus tractus solitarii of the rat. Mol Pharmacol. 2005;67(2):489-498.

63. Graves L, Lukert BP. Glucocorticoid-induced osteoporosis: a clinician's perspective. Clin Rev Bone Miner Metab. 2004;2(2):79-90.

64. Shaker JL, Lukert BP. Osteoporosis associated with excess glucocorticoids. Endocrinol Metab Clin North Am. 2005;34(2): 341-356, viii-ix.

65. Adinoff AD, Hollister JR. Steroid-induced fractures and bone loss in patients with asthma. N Engl J Med. 1983;309(5):265-268.

66. Van Staa TP, Leufkens HG, Abenhaim L, Zhang B, Cooper C. Use of oral corticosteroids and risk of fractures. $J$ Bone Miner Res. 2000;15(6):993-1000.

67. Kanis JA, Johansson H, Oden A, et al. A meta-analysis of prior corticosteroid use and fracture risk. J Bone Miner Res. 2004;19(6):893-899.

68. Wong CA, Walsh LJ, Smith CJP, et al. Inhaled corticosteroid use and bone-mineral density in patients with asthma. Lancet. 2000; 355(9213):1399-1403.

69. Van Staa TP, Leufkens HG, Cooper C. Use of inhaled corticosteroids and risk of fractures. J Bone Miner Res. 2001;16(3):581-588.

70. Cooper MS, Rabbitt EH, Goddard PE, Bartlett WA, Hewison M, Stewart PM. Osteoblastic 11beta-hydroxysteroid dehydrogenase type 1 activity increases with age and glucocorticoid exposure. J Bone Miner Res. 2002;17(6):979-986.

71. Weinstein RS, Jilka RL, Parfitt AM, Manolagas SC. Inhibition of osteoblastogenesis and promotion of apoptosis of osteoblasts and osteocytes by glucocorticoids. Potential mechanisms of their deleterious effects on bone. J Clin Invest. 1998;102(2):274-282.

72. Odell WD. Testosterone treatment of men treated with glucocorticoids (editorial). Arch Intern Med. 1996;156(11):1133-1134.

73. La Brocca A, Terzolo M, Pia A, Paccotti P, de Giuli P, Angeli A. Recurrent thromboembolism as a hallmark of Cushing's syndrome. J Endocrinol Invest. 1997;20(4):211-214.

74. Erem C, Nuhoglu I, Yilmaz M, et al. Blood coagulation and fibrinolysis in patients with Cushing's syndrome: increased plasminogen activator inhibitor-1, decreased tissue factor pathway inhibitor, and unchanged thrombin-activatable fibrinolysis inhibitor levels. J Endocrinol Invest. 2009;32(2):169-174.

75. Patrassi GM, Dal Bo Zanon R, Boscaro M, Martinelli S, Girolami A. Further studies on the hypercoagulable state of patients with Cushing's syndrome. Thromb Haemost. 1985;54(2):518-520.

76. Oikarinen A, Hoythya M, Jarvinen M. Dexamethasone-induced plasminogen activator inhibitor: characterization, purification, and preparation of monoclonal antibodies. Arch Dermatol Res. 1990; 282(3):153-158

77. Barouski-Miller PA, Gelehrter TD. Paradoxical effects of glucocorticoids on regulation of plasminogen activator activity of rat hepatoma cells. PNAS. 1982;79(7):2319-2322.

78. Brotman DJ, Girod JP, Posch A, et al. Effects of short-term glucocorticoids on hemostatic factors in healthy volunteers. Thromb Res. 2006;118(2):247-252.

79. Hasselgren PO. Glucocorticooids and muscle catabolism. Curr Opin Clin Nutr Metab Care. 1999;2(3):201-205.

80. Williams TJ, O’Hehir RE, Czarny D, Horne M, Bowes G. Acute myopathy in severe acute asthma treated with intravenously administered corticosteroids. Am Rev Respir Dis. 1988;137(2):460-463.

81. Van Marle W, Woods KL. Acute hydrocortisone myopathy. Br Med J. 1980;281(6235):271-272.
82. Larsson $\mathrm{H}$, Ahren $\mathrm{B}$. Insulin resistant subjects lack islet adaptation to short-term dexamethasone-induced reduction in insulin sensitivity. Diabetologia. 1999;42(8):936-943.

83. Henriksen JE, Alford F, Ward GM, Beck-Nielsen H. Risk and mechanism of dexamethasone-induced deterioration of glucose tolerance in non-diabetic first-degree relatives of NIDDM patients. Diabetologia. 1997;40(12):1439-1448.

84. Rizza RA, Mandarino LJ, Gerich JE. Cortisol-induced insulin resistance in man: impaired suppression of glucose production and stimulation of glucose utilization due to a postreceptor detect of insulin action. J Clin Endocrinol Metab. 1982;54(1):131-138.

85. Henriksen JE, Alford F, Vaag A, Handberg A, Beck-Nielsen H. Intracellular skeletal muscle glucose metabolism is differentially altered by dexamethasone treatment of normoglycemic relatives of type 2 diabetic patients. Metabolism. 1999;48(9):1128-1135.

86. Ekstrand A, Schalin-Jantti C, Lofman M, et al. The effect of (steroid) immunosuppression on skeletal muscle glycogen metabolism in patients after kidney transplantation. Transplantation. 1996;61(6): 889-893.

87. Schakman O, Gilson H, Thissen JP. Mechanisms of glucocorticoidinduced myopathy. J Endocrinol. 2008;197(1):1-10.

88. Krebs M, Krssak M, Bernroider E, et al. Mechanism of amino acidinduced skeletal muscle insulin resistance in humans. Diabetes. 2002; 51(3):599-605.

89. Dinneen S, Alzaid A, Miles J, Rizza R. Effects of the normal nocturnal rise in cortisol on carbohydrate and fat metabolism in IDDM. Am J Physiol. 1995;268(4 Pt 1):E595-E603.

90. Taskinen MR, Nikkila EA, Pelkonen R, Sane T. Plasma lipoproteins, lipolytic enzymes, and very low density lipoprotein triglyceride turnover in Cushing's syndrome. J Clin Endocrinol Metab. 1983;57(3):619-626.

91. Wajchenberg BL. Subcutaneous and visceral adipose tissue: their relation to the metabolic syndrome. Endocr Rev. 2000;21(6): 697-738

92. Parekh S, Anania FA. Abnormal lipid and glucose metabolism in obesity: implications for nonalcoholic fatty liver disease. Gastroenterology. 2007;132(6):2191-2207.

93. Nielsen MF, Caumo A, Chandramouli V, et al. Impaired basal glucose effectiveness but unaltered fasting glucose release and gluconeogenesis during short-term hypercortisolemia in healthy subjects. Am J Physiol Endocrinol Metab. 2004;286(1):E102-E110.

94. Rooney DP, Neely RD, Cullen C, et al. The effect of cortisol on glucose/glucose-6-phosphate cycle activity and insulin action. J Clin Endocrinol Metab. 1993;77(5):1180-1183.

95. Morton NM, Seck1 JR. 11beta-hydroxysteroid dehydrogenase type 1 and obesity. Front Horm Res. 2008;36:146-164.

96. Fasshauer M, Paschke R. Regulation of adipocytokines and insulin resistance. Diabetologia. 2003;46(12):1594-1603.

97. Beard JC, Halter JB, Best JD, Pfeifer MA, Porte D Jr. Dexamethasoneinduced insulin resistance enhances B cell responsiveness to glucose level in normal men. Am J Physiol. 1984;247(5 Pt 1): E592-E596.

98. Grill V, Pigon J, Hartling SG, Binder C, Efendic S. Effects of dexamethasone on glucose-induced insulin and proinsulin release in low and high insulin responders. Metabolism. 1990;39(3): 251-258.

99. Matsumoto K, Yamasaki H, Akazawa S, et al. High-dose but not low-dose dexamethasone impairs glucose tolerance by inducing compensatory failure of pancreatic beta-cells in normal men. $J$ Clin Endocrinol Metab. 1996;81(7):2621-2626.

100. Besse C, Nicod N, Tappy L. Changes in insulin secretion and glucose metabolism induced by dexamethasone in lean and obese females. Obes Res. 2005;13(2):306-311.

101. Mancini T, Kola B, Mantero F, Boscaro M, Arnaldi G. High cardiovascular risk in patients with Cushing's syndrome according to $1999 \mathrm{WHO} / \mathrm{ISH}$ guidelines. Clin Endocrinol (Oxf). 2004;61(6): 768-777. 
102. Wei L, MacDonald TM, Walker BR. Taking glucocorticoids by prescription is associated with subsequent cardiovascular disease. Ann Intern Med. 2004;141(10):764-770.

103. Souverein PC, Berard A, van Staa TP, et al. Use of oral glucocorticoids and risk of cardiovascular and cerebrovascular disease in a population based case-control study. Heart. 2004;90(8):859-865.

104. Hole DJ, Watt GC, Davey-Smith G, Hart CL, Gillis CR, Hawthorne VM. Impaired lung function and mortality risk in men and women: findings from the Renfrew and Paisley prospective population study. BMJ. 1996;313(7059):711-715.

105. DeMaria AN. Relative risk of cardiovascular events in patients with rheumatoid arthritis. Am J Cardiol. 2002;89(6A):33D-38D.

106. Uddhammar A, Eriksson AL, Nystrom L, Stenling R, RantapaaDahlqvist S. Increased mortality due to cardiovascular disease in patients with giant cell arteritis in northern Sweden. J Rheumatol. 2002;29(4):737-742.

107. Nashel DJ. Is atherosclerosis a complication of long-term corticosteroid treatment? Am J Med. 1986;80(5):925-929.

108. Maxwell SR, Moots RJ, Kendall MJ. Corticosteroids: do they damage the cardiovascular system? Postgrad Med J. 1994;70(830):863-870.

109. Bertram CE, Hanson MA. Prenatal programming of postnatal endocrine responses by glucocorticoids. Reproduction. 2002;124(4): 459-467.

110. Kay HH, Bird IM, Coe CL, Dudley DJ. Antenatal steroid treatment and adverse fetal effects: what is the evidence? J Soc Gynecol Investig. 2000;7(5):269-278.

111. Newnham JP. Is prenatal glucocorticoid administration another origin of adult disease? Clin Exp Pharmacol Physiol. 2001;28(11): 957-961.

112. Langley-Evans SC, Sherman RC, Welham SJ, Nwagwu MO, Gardner DS, Jackson AA. Intrauterine programming of hypertension: the role of the renin-angiotensin system. Biochem Soc Trans. 1999; 27(2):88-93

113. Benediktsson R, Lindsay R, Noble J, Seckl JR, Edwards CR. Glucocorticoid exposure in utero: new model for adult hypertension. Lancet. 1993;341(8841):339-341.

114. Connell JM, Whitworth JA, Davies DL, Lever AF, Richards AM, Fraser R. Effects of ACTH and cortisol administration on blood pressure, electrolyte metabolism, atrial natriuretic peptide and renal function in normal man. J Hypertens. 1987;5(4):425-433.
115. Kelly JJ, Tam SH, Williamson PM, Lawson J, Whitworth JA. The nitric oxide system and cortisol-induced hypertension in humans. Clin Exp Pharmacol Physiol. 1998;25(11):945-946.

116. Turner SW, Wen C, Li M, Fraser TB, Whitworth JA. Adrenocorticotrophin dose-response relationships in the rat: haemodynamic, metabolic and hormonal effects. J Hypertens. 1998;16(5):593-600.

117. Whitworth JA. Adrenocorticotrophin and steroid-induced hypertension in humans. Kidney Int Suppl. 1992;37:S34-S37.

118. Mills EH, Coghlan JP, Denton DA, Spence CD, Whitworth JA, Scoggins BA. The effect of sodium depletion and potassium loading on cortisol induced hypertension in sheep. Acta Endocrinol (Copenh). 1986;113(2):298-304.

119. Whitworth JA, Saines D, Scoggins BA. Potentiation of ACTH hypertension in man with salt loading. Clin Exp Pharmacol Physiol. 1985;12(3):239-243.

120. Humphrey TJ, Fan JS, Coghlan JP, et al. Inter-relationships between sodium and potassium intake and the blood pressure effects of ACTH in sheep. J Hypertens. 1983;1(1):19-26.

121. Hu L, Zhang Y, Lim PS, et al. Apocynin but not L-arginine prevents and reverses dexamethasone-induced hypertension in the rat. $\mathrm{Am} \mathrm{J}$ Hypertens. 2006;19(4):413-418.

122. Mondo CK, Zhang Y, de Macedo Possamai V, et al. N-acetylcysteine antagonizes the development but does not reverse ACTH-induced hypertension in the rat. Clin Exp Hypertens. 2006;28(2):73-84.

123. Zhang Y, Chan MM, Andrews MC, et al. Apocynin but not allopurinol prevents and reverses adrenocorticotropic hormone-induced hypertension in the rat. Am J Hypertens. 2005;18(7):910-916.

124. Wen C, Li M, Fraser T, Wang J, Turner SW, Whitworth JA. L-arginine partially reverses established adrenocorticotrophin-induced hypertension and nitric oxide deficiency in the rat. Blood Press. 2000; 9(5):298-304.

125. Zhang Y, Miao Y, Whitworth JA. Aspirin prevents and partially reverses adrenocorticotropic hormone-induced hypertension in the rat. Am J Hypertens. 2007;20(11):1222-1228

126. Li M, Wen C, Martin A, Whitworth JA. Dehydroepiandrosterone does not prevent adrenocorticotrophin-induced hypertension in conscious rats. Clin Exp Pharmacol Physiol. 1996;23(5):435-437.
Integrated Blood Pressure Control

\section{Publish your work in this journal}

Integrated Blood Pressure Control is an international, peer-reviewed open-access journal focusing on the integrated approach to managing hypertension and risk reduction. Treating the patient and comorbidities together with diet and lifestyle modification and optimizing healthcare resources through a multidisciplinary team approach constitute key

\section{Dovepress}

features of the journal. This journal is indexed on American Chemical Society's Chemical Abstracts Service (CAS). The manuscript management system is completely online and includes a very quick and fair peer-review system, which is all easy to use. Visit http://www.dovepress. com/testimonials.php to read real quotes from published authors. 